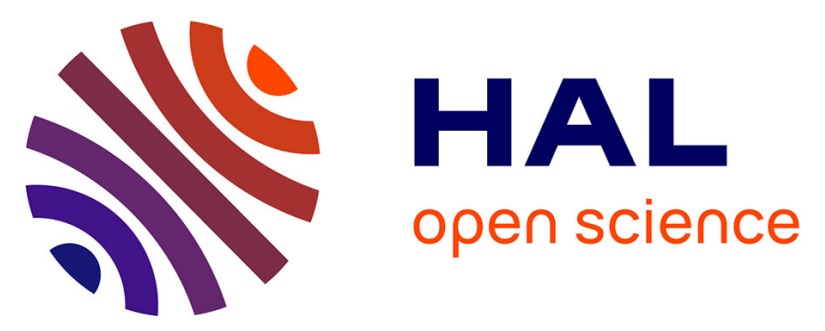

\title{
Vocalizations of the rare and flagship species Pharomachrus mocinno (Aves: Trogonidae): implications for its taxonomy, evolution and conservation
}

Pablo Bolaños-Sittler, Jérôme Sueur, Jérome Fuchs, Thierry Aubin

\section{- To cite this version:}

Pablo Bolaños-Sittler, Jérôme Sueur, Jérome Fuchs, Thierry Aubin. Vocalizations of the rare and flagship species Pharomachrus mocinno (Aves: Trogonidae): implications for its taxonomy, evolution and conservation. Bioacoustics, 2020, 29 (6), pp.654-669. 10.1080/09524622.2019.1647877. mnhn02279143

\section{HAL Id: mnhn-02279143}

\section{https://hal-mnhn.archives-ouvertes.fr/mnhn-02279143}

Submitted on 5 Sep 2019

HAL is a multi-disciplinary open access archive for the deposit and dissemination of scientific research documents, whether they are published or not. The documents may come from teaching and research institutions in France or abroad, or from public or private research centers.
L'archive ouverte pluridisciplinaire HAL, est destinée au dépôt et à la diffusion de documents scientifiques de niveau recherche, publiés ou non, émanant des établissements d'enseignement et de recherche français ou étrangers, des laboratoires publics ou privés. 
1 Vocalizations of the rare and flagship species Pharomachrus mocinno (Aves:

2 Trogonidae): implications for its taxonomy, evolution and conservation

4 Pablo Bolaños-Sittler ${ }^{\mathrm{a}, \mathrm{b}}$, Jérôme Sueur ${ }^{\mathrm{a}}$, Jérôme Fuchs ${ }^{\mathrm{a}}$, Thierry Aubin ${ }^{\mathrm{b}}$

6 a Institut de Systématique, Évolution, Biodiversité (ISYEB), Muséum national d'Histoire

7 naturelle, CNRS, Sorbonne Université, EPHE, 57 rue Cuvier, CP 50, F-75005, Paris, France

8

$9{ }^{b}$ Equipe Communications Acoustiques, Neuro-PSI, UMR 9197 CNRS-Université Paris-Sud,

1091405 Orsay, France

11

12 * Institut de Systématique, Évolution, Biodiversité (ISYEB), Muséum national d'Histoire

13 naturelle, CNRS, Sorbonne Université, 57 rue Cuvier, CP 50, F-75005, Paris, France

14 Tel : +330140793134

15 Email pablo.bolanos@edu.mnhn.fr 
24 Vocalizations of the rare and flagship species Pharomachrus mocinno (Aves:

25 Trogonidae): implications for its taxonomy, evolution and conservation

27 Abstract

28 The Resplendent Quetzal Pharomachrus mocinno is a rare Neotropical bird included in the IUCN

29 red list as Near Threatened. Fragmentation of its habitat, the cloud forest, is considered as the

30 principal threat. Two subspecies are currently recognized but genetic and morphometric studies

31 suggested they could be considered as full species. We assessed whether male vocalizations

32 would support a species delimitation hypothesis. We recorded in the field and downloaded from

33 sound archives vocalizations of 57 individuals from 30 different localities distributed in 11

34 countries. We estimated the acoustic differences of all the Pharomachrus taxa with multivariate

35 analyses and machine learning techniques. Our results show vocal differences between $P . m$.

36 mocinno and P. m. costaricensis that could have a molecular basis, potentially due to genetic drift

37 developed during the more than three million years of separation of P. m. mocinno (from Mexico

38 to Nicaragua) and P. m. costaricensis (Costa Rica and Panama). We therefore suggest that $P$.

39 mocinno could potentially be divided into two species. A possible separation of these taxa into

40 two species could have important consequences for the conservation status of the Resplendent

41 Quetzals, and redirect conservation efforts for these taxa.

42

43 Key words: territorial vocalization - Pharomachrus mocinno - Resplendent Quetzal 44 Trogonidae - conservation 


\section{Introduction}

The biological species concept is the main evolutionary concept considered to draw the lists of threatened species by the International Union for the Conservation of Nature Red List (IUCN 2001) which are mainly used to rule national and international policy for nature conservation (Isaac et al. 2004). The species level bears a particular importance for flagship species which act as symbols and attract public interest (Simberloff 1998). Most flagship species are large mammals such as the African elephant (Loxondota africana) for African savannah, the giant panda (Ailuropoda melanoleuca) for Chinese bamboo forest, the Bengal tiger (Panthera tigris) for Indian forest, the koala (Phascolarctos cinereus) for Australian eucalypt woodlands, or the humpback whale (Megaptera novaeangliae) for oceans (Courchamp et al. 2018; Groom et al. 2006). Bird species are more rarely used as a nature icon. One exception is the Resplendent Quetzal, Pharomachrus mocinno (De la Llave 1832) (Aves: Trogonidae), a rare Neotropical bird with highly coloured, bright and elongated feathers (LaBastille et al. 1972) and regarded as a symbol of Central American cloud forest. The Resplendent Quetzal is the centre of the Guatemalan heritage since the Mayan civilizations, being represented in all sorts of arts, drawn on the national flag, and used as the currency name (Bowes and Allen 1969). The Resplendent Quetzal is also considered a symbol of freedom, due to the belief that the species cannot live in captivity. Meanwhile there has been some successful captive reproduction programs, the task require a high level of technical knowledge (Morales-Divas, 2017).

In addition to its social influence, the Resplendent Quetzal plays a significant ecological role by dispersing the seeds of at least 32 tree species and by participating in the dynamics and resilience of the cloud forest (Solórzano et al. 2000). Pharomachrus mocinno is ranked in the

9 Near Threatened category of the IUCN Red List (Birdlife International 2016) and listed in the 0 Convention on International Trade in Endangered Species of Wild Fauna and Flora Appendix I of 
71 the most endangered species (UNEP-WCMC (Comps.) 2014). The distribution of the

72 Resplendent Quetzal shows an insular pattern limited to well preserved cloud forests in the south

73 of Mexico, Guatemala, El Salvador, Nicaragua, Honduras, Costa Rica and Panama (Solórzano et

74 al. 2003).

75

76

77

78

79

Pharomachrus mocinno was originally described by the Mexican naturalist Pablo de la Llave from specimens collected between 1787 and 1803 in Guatemala ('Goatemala') by the Royal Botanical Expedition to New Spain (De la Llave 1832). The name of the specific epithet, mocinno, was dedicated to the naturalist José Mariano Mociño, who participated in the expedition, and the genus name referred to the main body characteristics of the bird, pharos meaning mantle and makros meaning long in ancient Greek. In 1869, the German ornithologist Jean-Louis Cabanis revealed that male specimens from Costa-Rica were smaller than male specimens from Guatemala, motivating the creation of a new subspecies named $P . m$. costaricensis (Cabanis 1869). This subspecies distinction still persists with the populations of south Mexico, Guatemala, Honduras, El Salvador and Nicaragua classified as P. m. mocinno and the populations of Costa Rica and Panama classified as P. m. costaricensis (Birdlife International 2016). The distribution areas of the two subspecies are separated by the Nicaraguan depression, a $50 \mathrm{~km}$ wide, $600 \mathrm{~km}$ long lowland that contains the two largest lakes from Central America, namely the Lake Nicaragua and the Lake Managua (Marshall 2007). The age of this barrier, which is also known as the biological border region of Nicaragua (Weyl 1980), is not precisely established but arose between the early Pliocene ( 5 million years ago) and the beginning of the

Pleistocene (1.8 million years ago), probably when the Panamanian Isthmus was formed three million years ago (Keigwin 1982; Solórzano et al. 2004). Phylogenetic analyses revealed two monophyletic groups, corresponding to each subspecies for which gene flow was possibly interrupted for three to six million years corresponding to the age of the Nicaraguan depression 
95 (Solórzano and Oyama 2009). The lack of current contact between the populations of the two 96 subspecies has also been evidenced by telemetry studies, showing that individuals of $P . m$. 97 costaricensis from Costa Rica had no contact with populations of $P$. m. mocinno from north 98 Nicaragua (Powell and Bjork 1995).

The taking of taxonomic decisions based on the "amount of genetic difference" as an

100 absolute criterion for deciding whether two operational taxonomic units are distinct species, is

101 not recommended (McDonough et al. 2008). Ideally to test the taxonomic status of candidate

102 populations for specieshood, genetic evidence should be supported by complementary character

103 evidences (Cotterill et al. 2014, Tobias et al., 2010).

104 Supporting the original observations of Jean-Louis Cabanis (1869), additional 105 observations suggest that $P$. m. mocinno has more brilliant golden feathers than $P . m$. 106 costaricensis and the female of $P . m$. mocinno has a slight crest when the female of $P . \mathrm{m}$. 107 costaricensis has no crest (Skutch, 1944; LaBastille et al., 1972). Recent morphometry analyses 108 revealed differences in size between the two subspecies, $P$. m. mocinno being larger than $P . m$ 109 costaricensis, having longer wings, a wider bill and longer and wider tail cover feathers (Schulz 110 and Eisermann 2017; Solorzano et al. 2009; Solórzano and Oyama 2009). Behavioural characters 111 play an important role in species isolation, geographic variation in songs and calls being of 112 particular importance for species delimitation (Wei et al. 2015). Apart from the oscine passerines, 113 hummingbirds, parrots and some sub-oscines such as the Three-wattled Bellbird Procnias 114 Tricarunculata (Saranathan et al., 2007) there is no evidence that other birds could learn their 115 vocalizations (Kroodsma and Konishi 1991, Kroodsma, 2005). The species P. mocinno, as non116 passerine bird, would not acquire vocalizations through learning processes and therefore would 117 not be subject to cultural evolution (Wei et al. 2015). Thus, the acoustic differences between 118 populations, if they exist, could be mainly related to genetic factors (Brown and Lemon 1979). 
119 Surprisingly, no comparison between the sounds produced by the two subspecies of P. mocinno 120 has been documented yet.

121 To clarify the subspecies vs species taxonomy (Solórzano and Oyama 2009), we 122 conducted an acoustic comparison between the two subspecies $P$. m. mocinno and P. m.

123 costaricensis and between all Pharomachrus taxa based on multivariate analyses and machine

124 learning techniques. Our analyses show that the acoustic signals of $P . m$ mocinno and $P . m$.

125 costaricensis differ, mostly in frequency parameters. We then discuss the possible consequences

126 of a taxonomy change, in terms of evolution and conservation.

127

128 Material and methods

129 Acoustic analysis

130 To assess the acoustic specificity of $P . m$. mocinno and $P . m$. costaricensis, the territorial

131 vocalization of the two subspecies were compared with each other, and with the territorial

132 vocalization of the four other closely related species $P$. antisianus, $P$. auriceps, $P$. fulgidus and $P$.

133 pavoninus. The territorial song of Pharomacrus was the only vocalization selected for this

134 comparison due to a clear functional and structural acoustic homology between species in the

135 family Trogonidae. The territorial song mainly consists of multiple repetitions of a two-note

136 syllable at fairly regular intervals, with little change in pitch (Johnsgard 2000). The territorial

137 song has already been used to make comparisons between species in the family (Ornelas et al. 138 2009).

139 Seven males of $P . m$. mocinno were visually localized and recorded in January and

140 February 2016 and 2017 during the peak of vocal activity in two protected areas of Guatemala:

141 the "Refugio del Quetzal", San Marcos (N 14 56' - W 91 52', $1531 \mathrm{~m}$ ) and "Los Andes",

142 Suchitepéquez private reserve $\left(14^{\circ} 32^{\prime}-91^{\circ} 11^{\prime}, 1992 \mathrm{~m}\right)$. Recordings were achieved with a 
143 Tascam digital recorder DR-100 MK II (44.1 kHz sampling frequency, dynamic range of 16 bit)

144 connected to a Sennheiser ME-67 directional microphone (frequency response: $40-20000 \mathrm{~Hz} \pm$

$1452.5 \mathrm{~dB}$ ). To increase the number of individuals and include other sites and the closely related

146 species, recordings of 50 individuals available in five sound libraries (Xeno-Canto, Macaulay

147 Library, Biblioteca de Sonidos de Aves de México, Laboratorio de Bioacústica de la Universidad

148 de Costa Rica, and Borror Laboratory of Bioacoustics) were included in the analysis, collected in

149 different locations and/or on different dates, or alternatively when the sound recordists specified

150 that the vocalizations belonged to different individuals. When the libraries provided sounds in

151 compressed $\mathrm{mp} 3$ format that are not ideal for sound analysis in birds (Araya-Salas et al. 2017),

152 recordings were systematically requested from the authors in wav format with a minimum

153 sampling rate of $44.1 \mathrm{kHz}$ and a dynamic range of 16 bit. A total of 57 individual recordings $(P$.

154 m. mocinno, $\mathrm{n}=21 ;$ P. m. costaricensis, $\mathrm{n}=15 ;$; . antisianus, $\mathrm{n}=7 ;$. P. auriceps, $\mathrm{n}=6 ;$; fulgidus

$155 \mathrm{n}=4 ;$ P. pavoninus $\mathrm{n}=4$ ) from 30 different localities distributed in 11 countries (Mexico,

156 Guatemala, Honduras, Costa Rica, Panama, Colombia, Venezuela, Ecuador, Peru, Bolivia and

157 Brazil) could be analysed (Figure 1, Supporting Information Table S1).

158 The vocalizations were analysed with Raven Pro 1.4 software

159 (www.birds.cornell.edu/raven) directly from on-screen measurement cursors on the oscillogram

160 for time parameters (time precision $=0.0232 \mathrm{~s}$ ) and on the spectrogram for frequency parameters

161 (Hanning window with a FFT of 1024 points and an overlap of 90\% between successive

162 windows, leading to a frequency precision of $21.5 \mathrm{~Hz}$ and a time precision of $0.0232 \mathrm{~s}$ ). Taking

163 measurements on the spectrogram might not be optimal due to limited time and frequency

164 precisions when proceeding formal description of vocalizations, but is valuable when doing

165 comparison between sounds when only relative differences matter. The parameters for each of

166 the two successive notes, note 1 and note 2, composing the syllable were: note duration (s), inter- 
167 note separation (s), peak frequency that is the frequency of highest energy (Hz), centre frequency

$168(\mathrm{~Hz})$, highest and lowest frequencies $(\mathrm{Hz})$, first and third frequency quartiles $(\mathrm{Hz})$ (the

169 frequencies that divide the selection into frequency intervals containing respectively $25 \%$ and

$17075 \%$ of the energy), frequency inter-quartile-range (difference between the first and third

171 frequency quartiles). The inter-syllable separation (s) was also measured. In addition, the

172 frequency modulation (FM) of each note was assessed by measuring the dominant frequency in a

173 series of 20 frequency measurements equally distributed in time along each note using the

174 package seewave 2.0.5 (Sueur et al. 2008) from the R 3.2.5 environment (Development Core

175 Team 2008). The first mathematical derivative of these time series was computed, and the

176 resulting positive and negative values were summed to obtain the positive and negative FM

177 respectively. The FM was then characterized by two features, the positive and negative FMs. In

178 total, a 57 individuals by 22 variables matrix was obtained (one temporal parameter, seven

179 frequency parameters, two FM parameters per note, one temporal parameter between notes, and

180 one temporal parameter between syllables) (Figure 2).

181 As the number of notes found for each individual varied from 12 to 639 , a random

182 subsample of 40 notes was applied for the individuals that produced more than 40 notes to ensure

183 balanced datasets. A total of 1738 notes were analysed. For each note, the average of each

184 parameter per individual was calculated. The spectrograms were generated with seewave with a

185 Fourier transform made of 2048 samples tapered with a Hanning window and with an overlap of $18687.5 \%$.

187 To test how the 22 acoustic features could classify correctly P. m. mocinno, P. m. 188 costaricensis and the closely related species, two supervised classification methods where 189 applied, used in machine learning, namely a multiclass linear discriminant analysis (LDA) for the 190 subspecies comparison (Fisher 1936) and a balanced random forest analysis (RF) (Breiman 2001) 
191 including the subspecies and the other Pharomachrus species. For the LDA, the data were first Z-

192 transformed and reduced to two dimensions with a principal component analysis (PCA). The

193 coordinates of the recordings according to the first two PCA axes were used as input data for the

194 LDA. The taxa names were used as an explained (dependent) variable so that the LDA classified

195 the recordings according to subspecies. A LDA confusion matrix was built to estimate the

196 percentage of correct classification, and PCA scores were plotted as a function of latitude to test

197 whether the territorial vocalizations of $P . m$. mocinno and $P . m$. costaricensis intergrade along

198 their distribution. Both PCA and LDA analyses were carried out with the R package ade4 (Dray

199 et al. 2016).

200 For the RF, a Breiman's RF algorithm was applied on the 57 by 22 matrix with the help of 201 the randomForest R package (Liaw and Wiener 2015). The RF analysis was designed so that the 202 six Pharomachrus taxa were defined as the explained (dependent) variable and the 22 acoustic 203 features as the explaining (independent) variables. A total of 4000 decision trees were built based 204 on a random sample with replacement among $63 \%$ of the observations. A confusion matrix was 205 built with an average error rate based on the observations not sampled, known as the out-of-bag 206 observations. The relative importance of the explaining variables, i.e. of the acoustic features, 207 was calculated using the Gini index.

208 A Chi-square test was conducted to evaluate if the number of individuals classified by the 209 LDA or the RF was significantly higher than a classification expected by chance.

Molecular analyses

212 The $255 \mathrm{bp}$ of the mitochondrial Control Region, of the 16 individuals of P. m. mocinno and 9 213 individuals of P. m. costaricensis, published by Solórzano et al. (2004), were reanalysed using 214 other statistics ( $\mathrm{Da}, \mathrm{dxy}$, uncorrected sequence divergence) classically used to assess genetic 
215 differentiation between two lineages. All analyses were performed in DNAsp 6.0 (Rozas et al. 216 2017).

218 Results

219 Spectrograms of the typical territorial vocalizations of each Phraromachrus taxa are compared in

220 Figure 3. The first two axes of the PCA, which explained $61.17 \%$ of the total variance, showed a 221 difference between P. m. mocinno and P. m. costaricensis (Figure 4). Plotting the PCA scores 222 with respect to latitude did not indicate that the territorial song intergrades and did not show any 223 trend according to latitude within each sub-species (Figure 5). The LDA obtained from the PCA 224 scores showed a clear differentiation between P. m. mocinno and P. m. costaricensis. The 225 confusion matrix returned $89.88 \%$ of correct classification (P. m. mocinno 19 of 21 individuals 226 assigned correctly, P. m. costaricensis 13 of 15 individuals assigned correctly), and exceeded 227 classification expected by chance (Chi-square test, d.f. $=1$, $\operatorname{chi}^{\wedge} 2=18.37, \mathrm{p}<0.001$ ) (Table 2 ). The 228 acoustic features of the two subspecies of Pharomachrus are shown in Table 1.

The RF classification showed that the most important acoustic features to classify the 230 Pharomachrus taxa were the peak and centre frequency of the second note, followed by the 231 centre frequency of the second and first note (Figure 6). These parameters were followed by the 232 third frequency quartile of the second and first notes, then the inter-syllable and inter-note 233 separation, the duration of the first note, the frequency inter-quartile of the second note, the peak 234 frequency of the first note and the duration of the second note. The lowest and highest 235 frequencies, the negative and positive FM and the frequency inter-quartile range of the two notes 236 did not appear as major discriminating parameters.

237 The confusion matrix built on the balanced RF classification revealed a high correct 238 classification rate for all the species and subspecies with $81.9 \%$ for P. m. mocinno (17 of 21 
239 individuals assigned correctly, $86.67 \%$ for $P$. m. costaricensis (13 of 15 individuals assigned 240 correctly), $100 \%$ for $P$. antisianus ( 7 of 7 individuals assigned correctly), $100 \%$ for $P$. auriceps

241 (6 of 6 individuals assigned correctly), 75\% for P. fulgidus (3 of 4 individuals assigned 242 correctly), and $100 \%$ for P. pavoninus (4 of 4 individuals assigned correctly) (Table 3 ), all rates 243 exceeded classification expected by chance (Chi-square test, d.f. $=25$, chi $^{\wedge} 2=221.1, \mathrm{p}<0.001$ ).

\section{Molecular analyses}

246 The divergence statistics in the $255 \mathrm{bp}$ fragment of the Control Region between P. m. mocinno 247 and P. m. costaricensis were: Da: 0.02763, dxy: 0.03091, uncorrected sequence divergence: $2483.1 \%$.

\section{Discussion}

\section{Acoustic difference between Pharomachrus taxa}

253 The acoustic analysis showed relatively important differences among the Pharomachrus species, 254 suggesting that each taxa bears a species signature in its song, a phenomenon commonly 255 observed in birds but also in other singing species (Obrist et al. 2010). In particular, we found a 256 difference in the acoustic parameters of $P$. mocinno and $P$. costaricensis, similar as it has been 257 reported for other learning and non-learning species where species status has been promoted 258 (Cadena and Cuervo 2010; Millsap et al. 2011; Sandoval et al. 2014, 2017). The correct 259 classification between the two taxa was high as revealed by the LDA classification and confirmed 260 by the RF classification among all Pharomachrus taxa. In the particular case of the RF, the

261 classification of the sub-species was slightly less successful that the classification of the other 
262 species except for $P$. fulgidus that included only four individuals. As non-passerine birds, species 263 of Pharomachrus are supposed not to learn their vocalizations (Kroodsma and Konishi 1991; 264 Kroodsma 2005; Saranathan et al. 2007), so such differences between species of the family 265 probably arise from genetic drift, acoustic adaptation to environments or sexual selection 266 cumulated by years of separation.

267 In numerous species, body size is negatively correlated to sound frequency, a larger 268 animal producing lower frequencies (Fletcher 2004; Martin et al. 2011). Here the peak, median, 269 lowest and highest frequencies of the territorial vocalization of males of P. mocinno were higher 270 than in P. costaricensis, when the first is significantly larger and heavier than the second (Schulz 271 and Eisermann 2017; Solórzano et al. 2009, Solórzano and Oyama 2009). Such discrepancy 272 between acoustics and morphology among-taxa has been observed for other bird species (Laiolo 273 and Rolando 2003) and might suggest the occurrence of physiological or environmental 274 evolutionary constraints. The morphological difference existing between the two species could be 275 the consequence of different sexual selective pressures within the populations of $P$. mocinno and 276 of $P$. costaricensis. This morphological difference may also indicate that following a potential 277 founder group, with representation of larger males, this characteristic is maintained by a sexual 278 selection process (Solórzano 2003). Moreover, plotting the discriminant function scores with 279 respect to latitude did not reveal trends that would suggest intergradation.

\section{Integrative taxonomy of the Resplendent Quetzal and implications for conservation}

A discrete molecular differentiation was found between the two $P$. mocinno taxa 283 (Solórzano et al. 2004; Solórzano and Oyama 2009), implying that there is no female mediated 284 gene flow between the two subspecies. The divergence we found between the two Resplendent 285 Quetzal taxa $(3.1 \%)$ is similar to that described between other bird sister-species (Frankham et al. 
2010), and in particular within the Trogonidae (1-4\% in ND2 for sister-species in the Neotropical

287 genus Trogon (DaCosta and Klicka 2008), 10-13\% in ND2 for sister-species in the Asian genus

Harpactes (Hosner et al. 2010)). The International Ornithological Committee (IOC) taxonomy

289 (Gill and Donsker 2017) for the genus Trogon was based on the results from DaCosta and Klicka

290 (2008) and resulted in the elevation of several subspecies to species status (e.g. T. mesurus, T.

291 ramoniamus) for 'traditional species' that were not monophyletic in DaCosta and Klicka (2008).

292 Monophyletic species (e.g. T. personatus, T. rufus) with strong genetic differentiation (8\%)

293 across their distribution were not split (Gill and Donsker 2017). The genetic differentiation

294 between the two P. mocinno subspecies is $3.1 \%$ for the analysed 255 bp of the Control Region

295 fragment which usually has a comparatively higher substitution rate than protein coding genes in

296 birds (Lerner et al. 2011). Furthermore, it could be difficult to representatively estimate the 297 genetic divergence from such a short fragment. From a phylogenetic perspective, the two

298 subspecies are reciprocally monophyletic and diverge from each other by a level of genetic

299 divergence that is the low end of the range of genetic divergence between undisputed species.

300 Hence, the short sequence data available so far need to be complemented by the analyses of 301 characters linked to the evolution of reproductive isolation (biometrics, vocalizations) are 302 necessary.

For ethical reasons, due to the fact that $P$. mocinno and of $P$. costaricensis are rare, 304 endangered and highly protected in Guatemala, it was not possible to conduct playback 305 experiments to test whether the individuals perceive the differences revealed by the analysis as 306 usually achieved in behavioural experiments (Freeman and Montgomery 2017). Nevertheless, 307 previous playback experiments showed that males of $P$. mocinno could respond to territorial 308 vocalizations of $P$. costaricensis (Solórzano and Oyama 2009) as actually did other species of the 309 family Trogonidae responding to the same vocalizations tested (2017 personal communication 
310 from S. Solorzano to PB, unreferenced). This failure to discriminate an allospecific song has been

311 reported in other bird species (Nelson 1998; Soha et al. 2016) and does not preclude that females

312 could discriminate allospecific territorial and courtship vocalizations in a mate choice context

313 (Seddon and Tobias 2007).

314 The acoustic differences between P. mocinno and $P$. costaricensis are in agreement with

315 the morphology differentiation (LaBastille et al. 1972; Schulz and Eisermann 2017; Solórzano

316 and Oyama 2009), the genetic differentiation that a lack of shared haplotype implying no female

317 mediated gene flow (Solórzano and Oyama 2009), and the absence of contact due to an important

318 geographical and climatic barrier (Powell and Bjork 1995).

Speciation is a continuous process on which it is often very difficult, if not impossible, to

320 place a boundary among populations, especially if the populations involved are allopatric.

321 Populations distributed along the speciation continuum are often characterized by a mosaic of

322 differentiation in characters involved in the evolution of reproductive isolation and this is

323 reflected in the two P. mocinno subspecies.

324 The taxonomic decision to erect $P$. mocinno and $P$. costaricensis at the species level 325 would have strong consequences for conservation. Traditional subspecies nomenclature can 326 provide a misleading impression of the true geographical pattern of intraspecific differentiation 327 along the speciation gradient and can arguably misdirect conservation effort (Zink 2004). At a 328 global level, the former P. m. mocinno is classified as a Near Threatened species (Birdlife 329 International 2016). Even though the two subspecies are at an intermediate level of 330 differentiation, where elevating them as full species or keeping them as subspecies could be a 331 matter of debate. A species level would imply a reduction of the area of occurrence and a 332 decrease of population density for each taxon. Therefore the conservation status must be 333 reconsidered for each taxon to a higher level of danger. Moreover, both P. m. mocinno and P. m. 
334 costaricensis are vulnerable due to a widespread deforestation, but the rate of habitat degradation

335 being higher for the former than for the later (Sofia Solórzano et al. 2003), the modification of the 336 conservation status could be higher for P. m. mocinno.

Based on multivariate acoustic analysis and machine learning techniques, we could 338 highlight an acoustic difference between $P . m$. mocinno and $P . m$. costaricensis, which could support a possible separation of these taxa into two species. Nevertheless, additional high-quality and well documented recordings of all Pharomachrus taxa would help in getting a better idea of variation inside the genus and further studies of differences in ecology and behaviour between the two subspecies are needed to decide if the subspecies could be regarded as two valid biological 343 species..

\section{Acknowledgements}

346 We are grateful to the guides Jesús Lucas and Selvin Xiloj for their useful help during field work 347 and their shared knowledge, to family Hazard for the support to conduct this study in Los Andes 348 reserve. We thank Sébastien Hardy and CEMCA for the important support to conduct the study 349 in Guatemala. We thank Camille Desjonquères, Juan Ulloa and Robin Simonot for their valuable 350 comments. We are grateful to Macaulay Library, Laboratorio de Bioacústica de La Universidad 351 de Costa Rica, Biblioteca de Sonidos de Aves de México, Borror Laboratory of Bioacoustics and 352 Xeno-Canto. We thank the recordists who shared their sounds: T. Parker, V. Emanuel, S. 353 Olmstead, M. Robbins, F. Schmitt, N. Krabbe, P. Boesman, D. Ross, C. Marantz, S. Gaunt, J. 354 Sánchez, P. Driver, E. Morton, A. Martínez, M. Medler, J. de León, A. LaBastille, S. Jones, F. 355 González-García, A. May, C. Duncan, C. Hanks, B. O’Shea, and K. Zimmer.

356 We are very grateful to Ricky Lopez Bruni for sharing the picture of the Resplendent 357 Quetzal. Special thanks to Andrew Horn and Nacho Areta for their valuable comments to 
358 improve this research article. Finally we thank Margarita Vides and Lillian Irving for the 359 improvement of the English.

361 Disclosure statement

362 No potential conflict of interest was reported by the authors.

\section{Funding}

365 This work was funding by the National Geographic Society [grant number 9479-6]. The first 366 author received a scholarship by Guatefuturo Foundation [69-2015].

368 Bibliography

369 Araya-Salas M, Smith-Vidaurre G, Webster M. 2017. Assessing the effect of sound file 370 compression and background noise on measures of acoustic signal structure. Bioacoustics. 4622(11): 1-17.

372 Birdlife International. 2016. Pharomachrus Mocinno. The IUCN Red List of Threatened Species 373 2016. [accessed 2018 Jul 31]. http://www.iucnredlist.org/details/22682727/0

374 Bowes AL, and Allen DG. 1969. Biology and conservation of the Quetzal. Biol. Conserv. 1(4): $375 \quad 297-306$.

376 Breiman L. 2001. Random forests. Mach. Learn. 45(1): 5-32.

377 Brown RN, Lemon RE. 1979. Structure and evolution of song form in the wrens Thryothorus $378 \quad$ sinaloa and T. felix. Behav. Ecol. Sociobiol. 5(2): 111-31.

379 Cabanis J. 1869. Der Vögel Costaricas und deren Lebensweise. J. für Ornithol. 17(2): 312-13.

380 Cadena CD, Cuervo AM. 2010. Molecules, ecology, morphology, and songs in concert: How 381 many species is Arremon torquatus (Aves: Emberizidae)? Biol. J. Linn. Soc. 99(1): 152-76. 
382 Cotterill FPD Taylor PJ, Gippoliti S, Bishop JM, Groves CP. 2014. Why one century of phenetics 383 is enough: Response to 'are there really twice as many bovid species as we thought?' Syst. 384 Biol. 63(5): 819-32.

385 Courchamp F, Jaric I, Celine A, Meinard Y, Ripple WJ, Chapron G. 2018. The paradoxical 386 extinction of the most charismatic animals. PLOS Biol. 16: 1-13.

387 DaCosta JM, Klicka J. 2008. The great American interchange in birds: a phylogenetic perspective $388 \quad$ with the genus Trogon. Mol. Ecol. 17: 1328-43.

389 Development Core Team. 2008. R: A language and environment for statistical computing. R $390 \quad$ Foundation for Statistical Computing. http://www.r-project.org.

391 Dray S, Du-Four AN, Thioulouse J. 2016. "Package 'Ade4.’”: 1-409.

392 Fisher RA. 1936. The Use of Multiple Measurements in Taxonomic Problems. Ann. Eugen. 7(2): $393 \quad 179-88$.

394 Fletcher NHA. 2004. Simple frequency-scaling rule for animal communication. J. Acoust. Soc. $395 \quad$ Am. (115): 2334-38.

396 Frankham R, Ballou JD, Briscoe DA, Mcinnes KH. 2010. Introduction to conservation genetics 397 2nd ed. Cambridge University Press. p. 618.

398 Freeman BG, Montgomery GA. 2017. Using song playback experiments to measure species recognition between geographically isolated populations: a comparison with acoustic trait analyses. Auk. 134(4): 857-70.

401 Gill F, Donsker D. 2017. IOC World Bird List (v 7.3).

402 Groom M, Meffe GK, Carroll CR. 2006. Principles of conservation biology. Sunderland: Sinauer 403 Associates, Inc.

404 Hosner PA, Sheldon FH, Lim HC, Moyle RG. 2010. Phylogeny and biogeography of the Asian 405 trogons (Aves: Trogoniformes) inferred from nuclear and mitochondrial DNA sequences. 
407 Isaac NJB, Mallet J, Mace GM. 2004. Taxonomic inflation: its influence on macroecology and $408 \quad$ conservation. Trends Ecol. Evol. 19(9): 464-69.

409 IUCN. 2001. Categories \& Criteria (Version 3.1). [Accessed 2018 Jul 31]. 410 http://www.iucnredlist.org/static/categories_criteria_3_1

411 Johnsgard PA 2000. Trogons and quetzals of the world. Smithsonian Institution Press. 412 Washington, DC.

413 Keigwin LD. 1982. Isotopic paleoceanography of the caribbean and East Pacific: role of Panama $414 \quad$ uplift on late neogene time. Science. 217(7): 350-53.

415 Kroodsma DE, Konishi M. 1991. A suboscine bird (Eastern Phoebe, Sayornis Phoebe) develops 416 normal song without auditory feedbak. Anim. Behav. 42:477-87.

417 Kroodsma D. (2005) The singing life of birds. Houghton Mifflin Company, 482 p

418 De la Llave P. 1832. Memoria sobre Quetzaltototl, género nuevo de Aves. Registro trimestre o 419 colección de memorias de historia, literatura, ciencias y artes. 1:43-49.

420 LaBastille A, Allen DG, Durrell LW. 1972. Behaviour and feather structure of the quetzal. Auk. 421 89(4): 339-48.

Laiolo P, Rolando A. 2003. The evolution of vocalizations in the genus corvus: effects of 424 Lerner HRL, Meyer M, James, HF, Hofreiter M, Fleischer RC, 2011. Multilocus resolution of 425 phylogeny and timescale in the extant adaptive radiation of hawaiian honeycreepers. Curr. 426 Biol. 21:1838-1844.

427 Liaw A, Wiener M. 2015. Package RandomForest. 54.1-54.10.

428 Marshall JS. 2007. In: Bundschuh and Alvarado, editors. The geomorphology and physiographic 429 provinces of Central America: geology and hazards. Taylor and Francis; 1:1-51. 
Martin JP, Doucet SM, Knox RC, Mennill DJ. 2011. Body size correlates negatively with the frequency of distress calls and songs of neotropical birds. J. F. Ornithol. 82(3):259-68.

432 McDonough MM, Ammerman LK, Timm RM, Genoways HH, Larsen PA, Baker RJ. 2008. Speciation within bonneted bats (genus Eumops): the complexity of morphological,

Obrist MK, Pavan G, Sueur J, Riede K, Llusia D, Márquez R. 2010. Bioacoustics approaches in Morales-Divas CA. 2017. Conservación del quetzal, (Pharomachrus mocinno) en cautiverio en el

zoológico Miguel Álvarez del Toro, Tuxtla Gutiérrez, Chiapas, México. Ciencia Animal: 4-

7.Nelson DA. 1998. Geographic variation in song of gambel 's White-Crowned Sparrow. Behaviour. 135: 321-42.

Millsap BA, Seipke SH, Clark WS. 2011. The Gray Hawk ( Buteo Nitidus ) is two species. Condor. 113(2):326-39.

\section{Corat}

biodiversity inventories. In Eymann J, Degreef J, Häuser C, Monje JC, Samyn Y, VandenSpiegel D, editors. Manual on field recording techniques and protocols for all taxa biodiversity inventories. Abc Taxa; p. 68-99.

Ornelas JF, Gonzalez C, Espinosa De Los Monteros A. 2009. Uncorrelated evolution between vocal and plumage coloration traits in the trogons: a comparative study. J. Evol. Biol. 22(3):471-84.

Powell GVN, Bjork R. 1995. Implications of intratropical migration on reserve design a case study using Pharomachrus mocinno. Conserv. Biol. 9(2):354-62.

Rozas J, Ferrer-Mata A, Sánchez-DelBarrio JC, Guirao-Rico S, Librado P, Ramos-Onsis SE, Sánchez-Gracia A. 2017. DnaSP 6: DNA sequence polymorphism analysis of large datasets.

453 Sandoval L, Bitton PP, Demko AD, Doucet SM, Mennill DJ, 2017. Phenotypic variation and 

(Aves: Passerellidae). Zootaxa. 4291(1):155-70.

456 Sandoval L, Bitton PP, Doucet SM, Mennill DJ, 2014. Analysis of plumage, morphology, and voice reveals species-level differences between two subspecies of Prevost's GroundSparrow Melozone biarcuata (Prévost and Des Murs) (Aves: Emberizidae). Zootaxa. 3895(1):103-16.

Morales-Divas CA. 2017. Conservación del quetzal, (Pharomachrus mocinno) en cautiverio en el zoológico Miguel Álvarez del Toro, Tuxtla Gutiérrez, Chiapas, México. Ciencia Animal: 4-7.

Schulz U, Eisermann K. 2017. Morphometric differentiation between subspecies of Resplendent Quetzal (Pharomachrus mocinno mocinno and P. m. costaricensis) based on male uppertailcoverts morphometric. Br. Ornithol. Club. 137(4):287-91.

Seddon N, Tobias JA. 2007. Song divergence at the edge of Amazonia: an empirical test of the peripatric speciation model. Biol. J. Linn. Soc. 90(1):173-88.

Simberloff D. 1998. Flagships, umbrellas, and keystones: is single species management passé in the landscape era? Biol. Cons. 83(3):247-57.

Soha, JA, Poesel A, Nelson DA, Lohr B. 2016. Non-salient geographic variation in birdsong in a species that learns by improvisation. Ethol. 122(4):343-53.

Solórzano S, Castillo S, Valverde T, Avila L. 2000. Quetzal abundance in relation to fruit availability in a cloud forest in southeastern Mexico. Biotropica. 32(3):523-32.

Solórzano S. 2003. Genética de la conservación del quetzal e impactos de la pérdida de sus hábitats reproductivos sobre su distribución [dissertation]. Morelia, Michoacán: Universidad Nacional Autónoma de México.

Solórzano S, Castillo-Santiago MA, Navarrete-Gutiérrez D, Oyama K. 2003. Impacts of the loss 
Solórzano S, Baker AJ, Oyama K. 2004. Conservation priorities for Resplendent Quetzals based on analysis of mitochondrial DNA control-region sequences. Condor. 106(3):449-56.

Solórzano S, Garcia-Juarez M, Oyama K. 2009. Genetic diversity and conservation of the resplendent quetzal Pharomachrus mocinno in Mesoamerica. Revista Mexicana De Biodiversidad. 80(1): 241-48.

Solórzano S, Oyama K. 2009. Morphometric and molecular differentiation between quetzal subspecies of Pharomachrus mocinno (Trogoniformes: Trogonidae). Rev. Biol. Trop. 58(1):357-71.

Sueur J, Aubin T, Simonis C. 2008. Sound analysis and synthesis with the package seewave. Bioacoustics. 18(2):213-26.

Tobias JA, Seddon N, Spottiswoode N, Pilgrim JD, Fishpool LDC, Collar NJ. 2010. Quantitative criteria for species delimitation. Ibis. 152:724-746.

UNEP-WCMC (Comps.). 2014. Checklist of CITES Species. CITES Secretariat, Geneva, Switzerland and UNEP-WCMC, Cambridge, United Kingdom. [accessed 2017 Nov 23].

Wei C, Jia C, Dong L, Wang D, Xia C, Zhang Y, Liang W. 2015. Geographic variation in the calls of the Common Cuckoo (Cuculus canorus): isolation by distance and divergence among subspecies. J. Ornithol. 156(2):533-42.

Weyl R. 1980. Geology of Middle America. Gebr. Born. Berlin and Stuttgart.

Zink RM. 2004. The role of subspecies in obscuring avian biological diversity and misleading conservation policy. Proc. R. Soc. B Biol. Sci. 271(1539):561-64. 


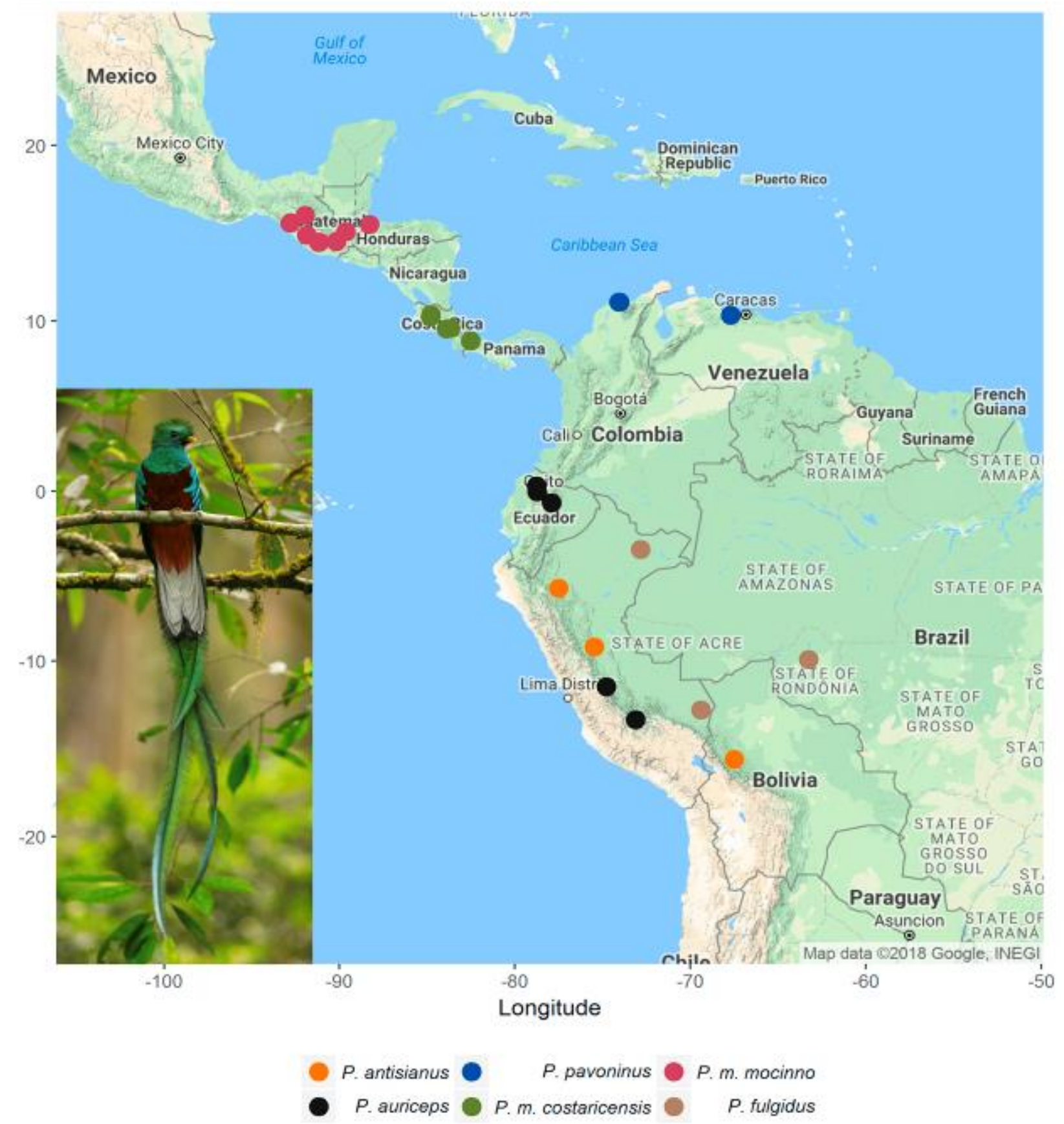

503 Figure 1: Map of Central America and north of South America showing the sites of recordings of 504 Pharomachrus species and subspecies used for the comparative analysis (Google® background).

505 Picture of $P$. m. mocinno, approximate body length $41 \mathrm{~cm}$ (picture reproduced with the 506 authorization of Ricky Lopez). 


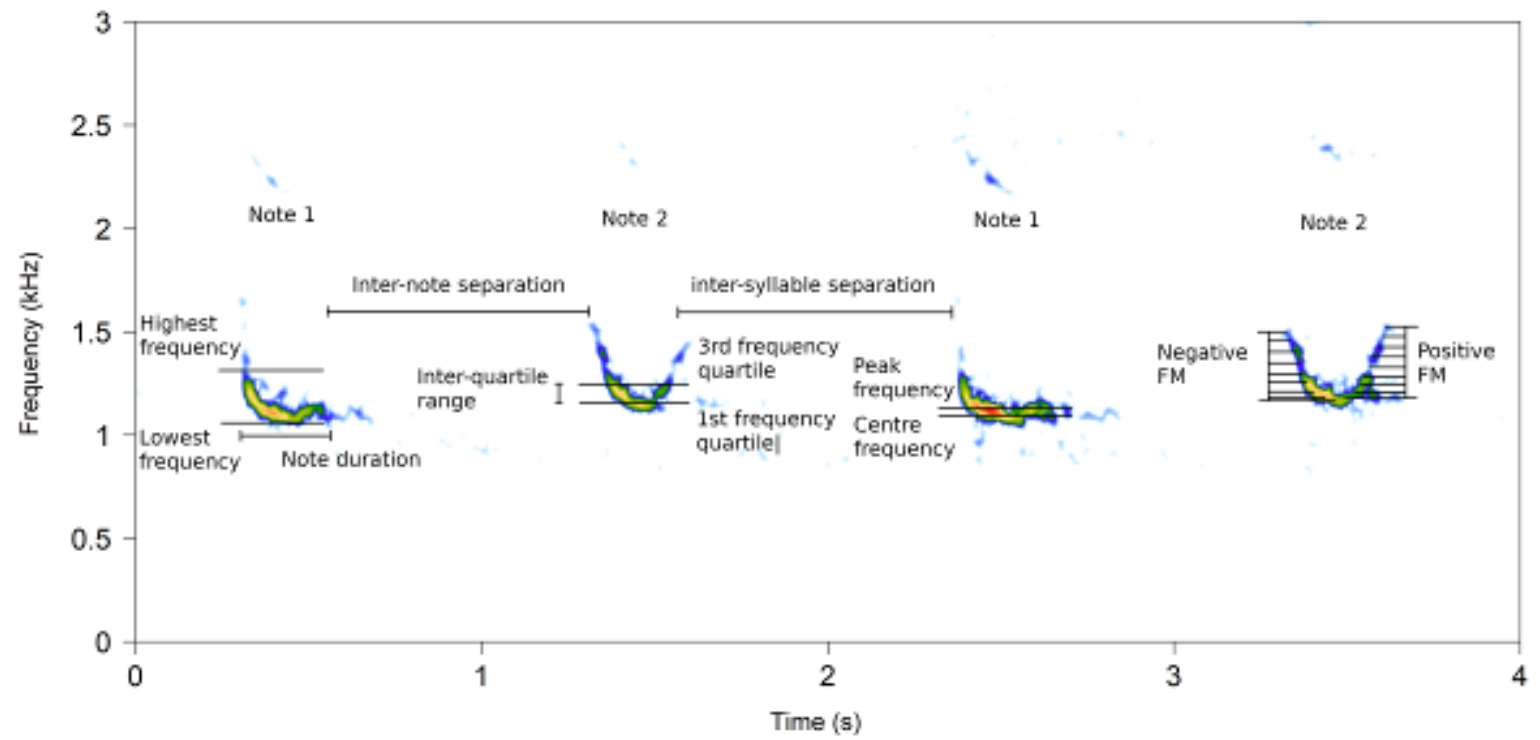

508

509 Figure 2: Annotated spectrogram of a male territorial vocalization of P. m. mocinno, showing the

510 time and frequency measurements (short-time Fourier transform parameters: Hann window made

511 of 2048 samples and $87.5 \%$ of overlap between successive windows).

512

513

514 


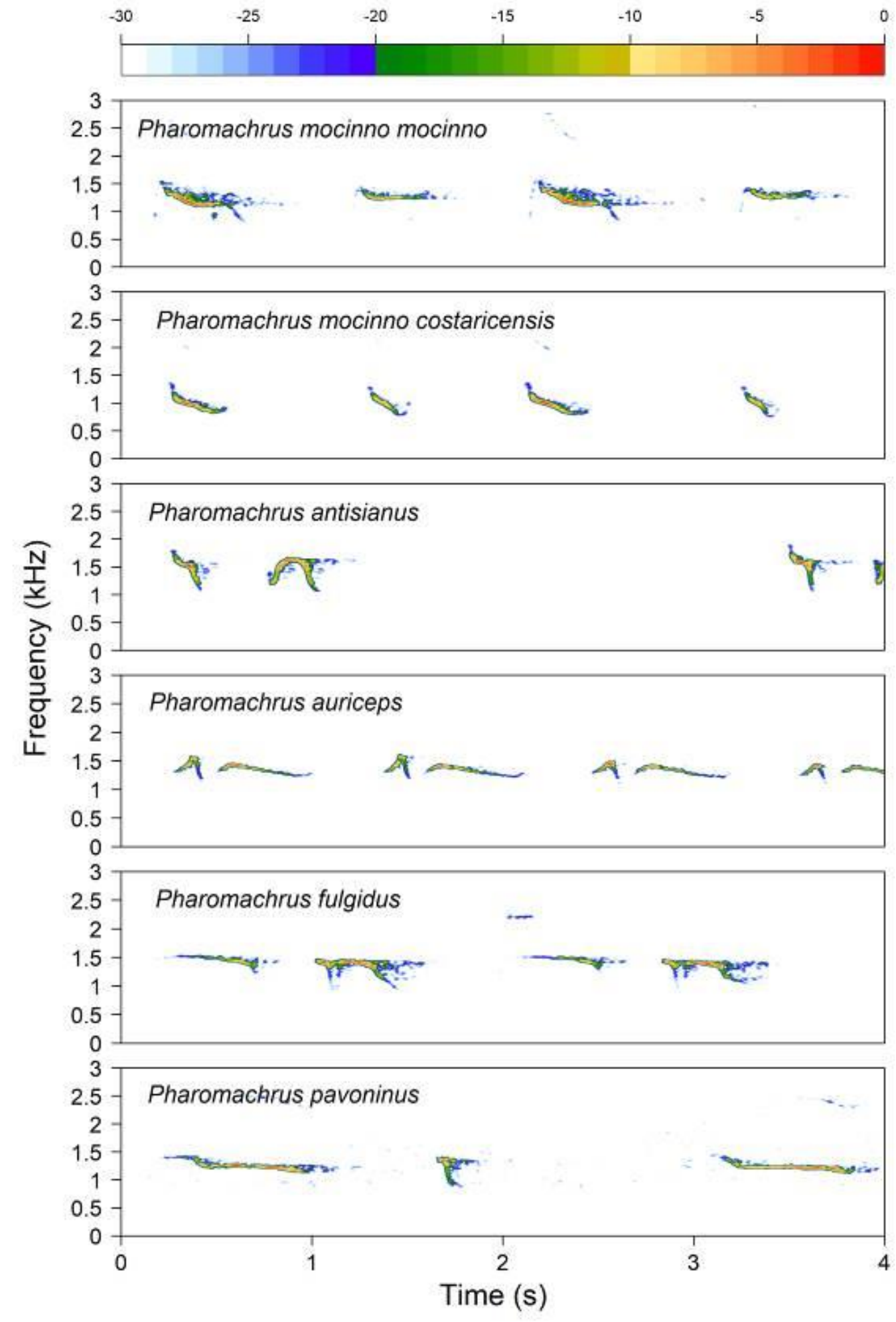

515

516 Figure 3: Spectrograms of the territorial vocalizations of $P . m$. mocinno, $P$. m. costaricensis, $P$.

517 antisianus, $P$. auriceps, $P$. fulgidus and $P$. pavoninus (Sound recordists in the same order: P. 
518 Bolaños, L. Baptista, C. Marantz, V. Emanuel, M. Robbins, P. Boesman) (short-time Fourier 519 transform parameters: Hanning window made of 2048 samples and $87.5 \%$ of overlap between 520 successive windows). The vocalizations were aligned to fit into a $4 \mathrm{~s}$ window to allow temporal 521 comparison.

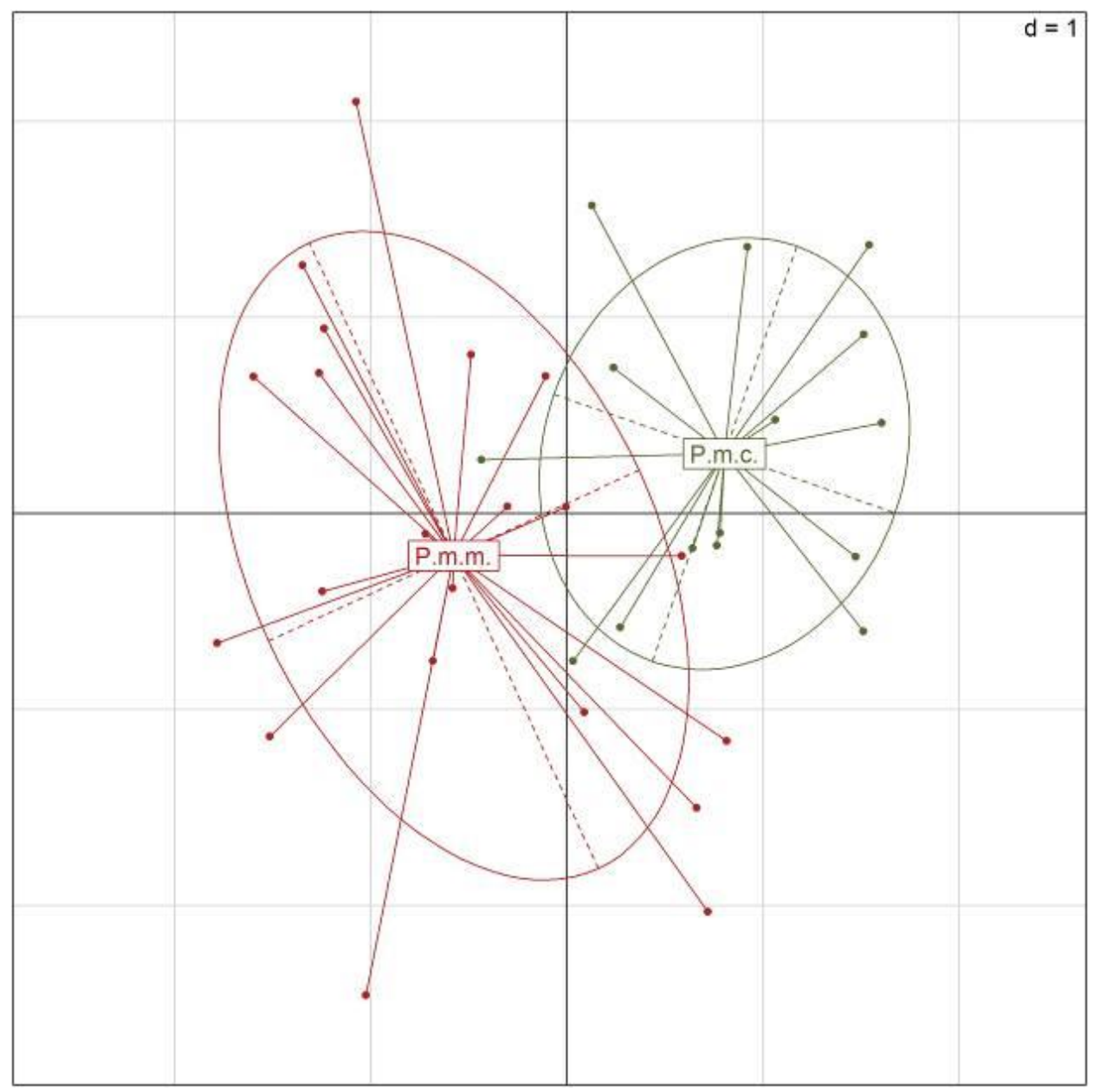

524 Figure 4: Principal Component Analysis (PCA) projection showing the space defined by the two 525 first principal axes that explained $61.17 \%$ of the total variance. Each point corresponds to a single 526 individual. Pharomachrus mocinno mocinno (P.m.m.) individuals are indicated in red and P. $m$. 527 costaricensis (P.m.c.) individuals in green. The ellipses surround the centroid of each taxa and 528 delimit $67 \%$ of the vocalizations that are expected to be associated with each taxa. 


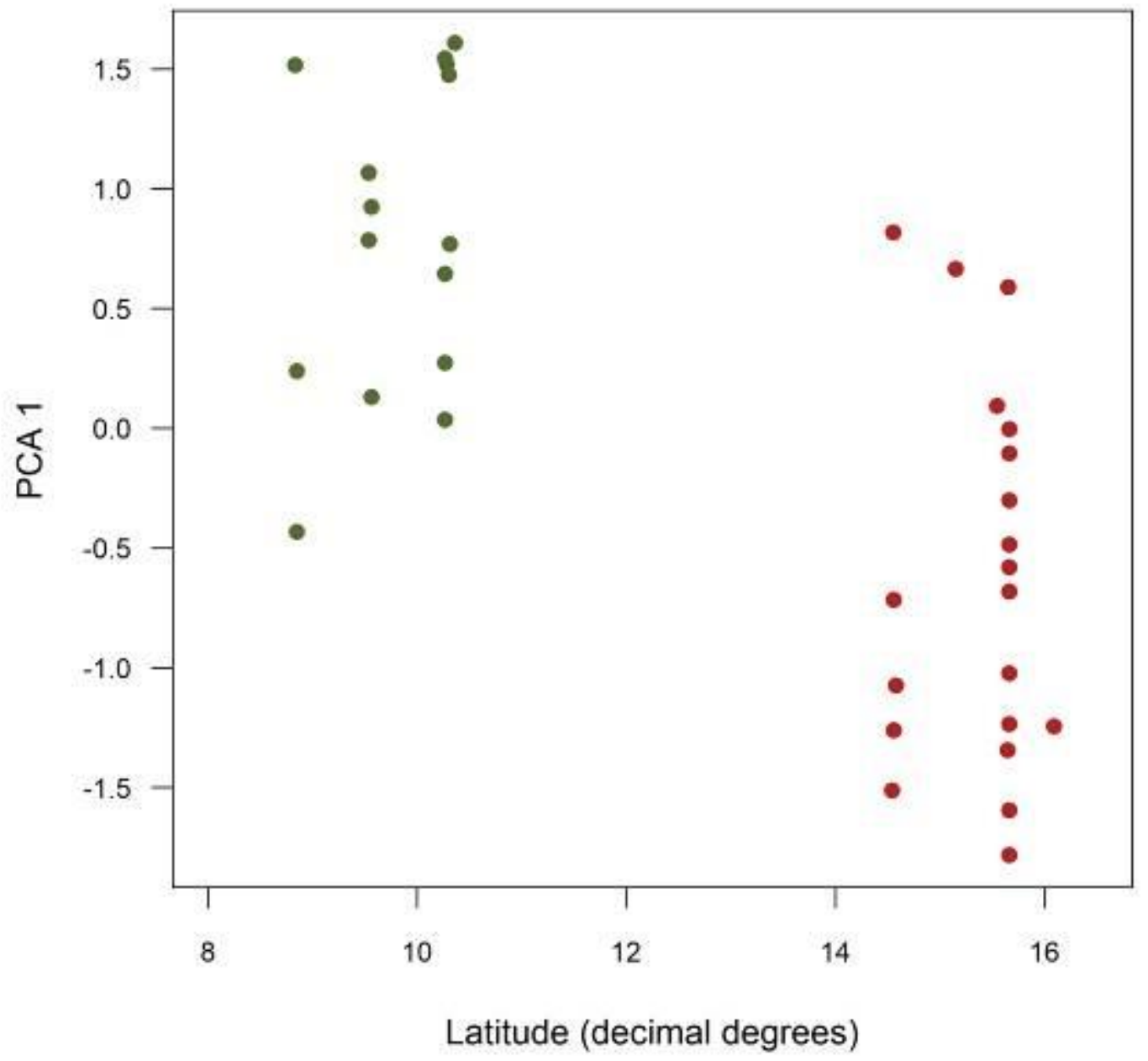

529

530 Figure 5: Scores obtained from principal component analysis (PCA) based on 22 acoustic 531 measurements of the song of $P$. m. mocinno (red dots) and $P$. m. costaricensis (green dots), 532 plotted as a function of latitude (total individuals is 21 P. m. mocinno and 15 P. m. costaricensis).

533 The gap in latitude between $11^{\circ}$ and $13^{\circ}$ is a gap in the distribution of $P$. mocinno related to the 534 lowlands of Nicaragua. 


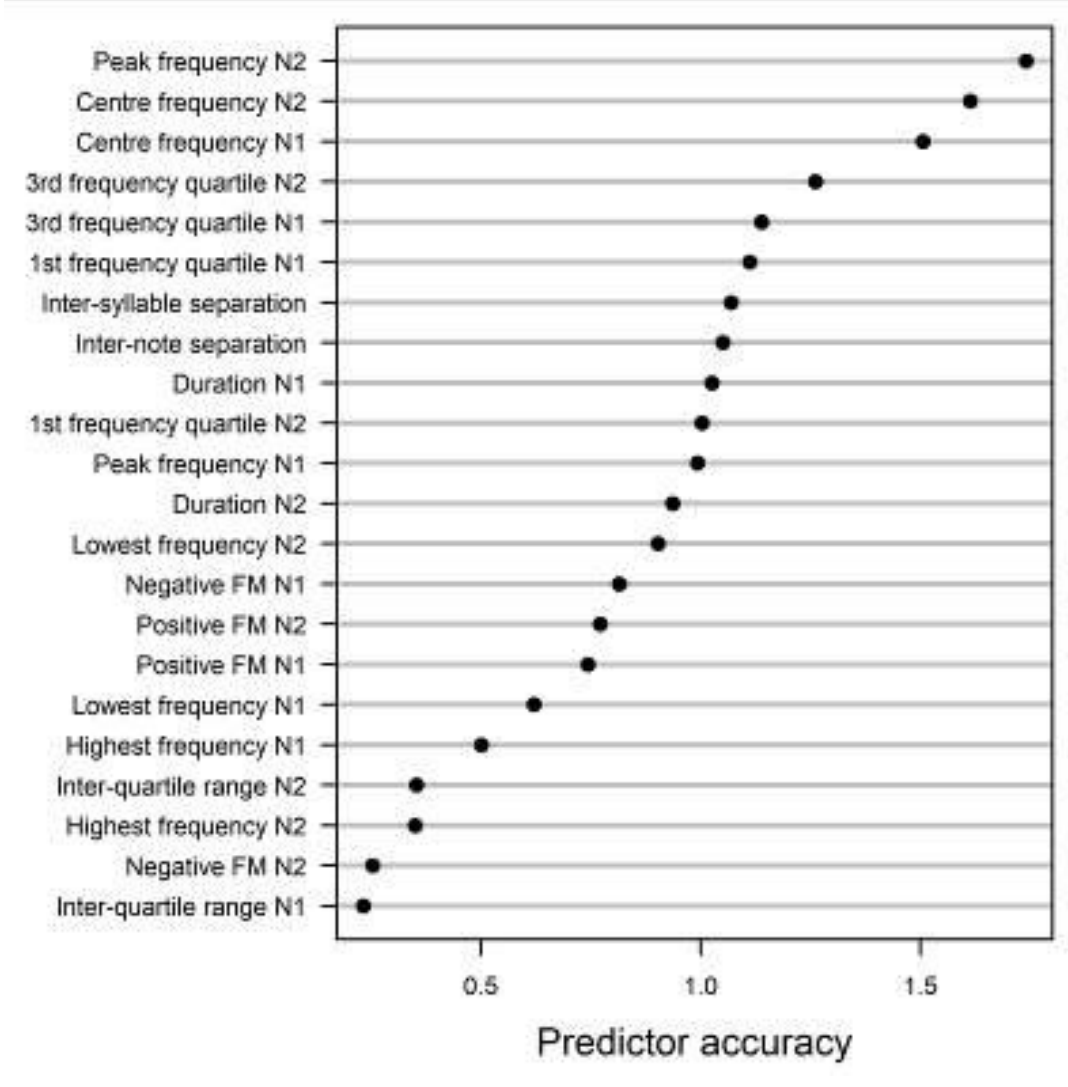

537 Figure 6: Random Forest analysis for Pharomachrus taxa. Relative importance of the explaining 538 variables based on the mean decrease Gini impurity criteria. 
548 Table 1: Characteristics of the territorial vocalization of $P . m$. mocinno and $P$. m. costaricensis

549 (21 individuals for P. m. mocinno and 15 individuals for P. m. costaricensis). Mean \pm SD (range).

\begin{tabular}{|c|c|c|}
\hline Acoustic Feature & P. m. mocinno & P. m. costaricensis \\
\hline Inter note separation (s) & $0.53 \pm 0.12(0.08-0.65)$ & $0.63 \pm 0.12(0.41-0.82)$ \\
\hline Inter syllable separation (s) & $0.68 \pm 0.16(0.38-1.01)$ & $0.6 \pm 0.09(0.4-0.73)$ \\
\hline \multicolumn{3}{|c|}{ Note 1} \\
\hline Duration (s) & $0.38 \pm 0.09(0.27-0.59)$ & $0.3 \pm 0.05(0.23-0.39)$ \\
\hline Center frequency $(\mathrm{Hz})$ & $1094.8 \pm 99.4(880.7-1205.9)$ & $986.1 \pm 82.87$ (865.9-1094.6) \\
\hline Highest frequency $(\mathrm{Hz})$ & $1462 \pm 140.53(1190-1728)$ & $1409 \pm 182.28(1147-1771)$ \\
\hline Lowest frequency $(\mathrm{Hz})$ & $910.7 \pm 145.19(678.8-1106)$ & $723.6 \pm 65.75(613-853.7)$ \\
\hline First frequency quartile $(\mathrm{Hz})$ & $1051.5 \pm 102.98(835.9-1169.1)$ & $933.3 \pm 84.03(816.5-1061.1)$ \\
\hline Third frequency quartile $(\mathrm{Hz})$ & $1143.2 \pm 81.61(954.3-1255.3)$ & $1035.2 \pm 77.02(905.6-1131.7)$ \\
\hline Inter-quartile range $(\mathrm{Hz})$ & $91.76 \pm 55.9(32.29-278.62)$ & $101.88 \pm 40.22(56.24-193.80)$ \\
\hline Peak frequency $(\mathrm{Hz})$ & $1098 \pm 95.66(889.3-1210.9)$ & $991.4 \pm 84.23(867-1109)$ \\
\hline Negative FM (Hz) & $1.65 \pm 0.43(0.83-2.53)$ & $1.5 \pm 0.33(0.98-1.99)$ \\
\hline Positive FM (Hz) & $1.61 \pm 0.42(0.95-2.49)$ & $1.48 \pm 0.29(1.03-1.99)$ \\
\hline \multicolumn{3}{|c|}{ Note 2} \\
\hline Duration (s) & $0.34 \pm 0.09(0.18-0.52)$ & $0.31 \pm 0.06(0.22-0.43)$ \\
\hline Center frequency $(\mathrm{Hz})$ & $1164 \pm 84.66(1006-1343)$ & $987.6 \pm 67.21(893.6-1100.5)$ \\
\hline Highest frequency (Hz) & $1439 \pm 129.81(1212-1643)$ & $1324 \pm 131.78(1154-1679)$ \\
\hline Lowest frequency $(\mathrm{Hz})$ & $970.8 \pm 135.94(731.2-1196.5)$ & $774.9 \pm 68.65(689.7-913.3)$ \\
\hline First frequency quartile $(\mathrm{Hz})$ & $1115.5 \pm 100.73(943.9-1319.7)$ & $931.2 \pm 81.95(802.1-1065.3)$ \\
\hline Third frequency quartile $(\mathrm{Hz})$ & $1210 \pm 81.61(1072-1366)$ & $1046.2 \pm 77.02(970.3-1134.1)$ \\
\hline Inter-quartile range $(\mathrm{Hz})$ & $94.55 \pm 55.91(30.88-343.56)$ & $114.95 \pm 40.22(37.49-199.95)$ \\
\hline Peak frequency $(\mathrm{Hz})$ & $1168 \pm 81.47(1036-1354)$ & $992.8 \pm 68.29(881.2-1108.4)$ \\
\hline Negative FM (Hz) & $1.64 \pm 0.49(0.63-2.53)$ & $1.54 \pm 0.32(1.01-2.1)$ \\
\hline Positive FM (Hz) & $1.66 \pm 0.49(0.66-2.6)$ & $1.54 \pm 0.3(1.13-2.1)$ \\
\hline
\end{tabular}


550 Table 2: LDA confusion matrix used to classify the species belonging to P. m. mocinno or P. $m$.

551 costaricensis, based on 22 acoustic measurements of the territorial vocalizations (21 individuals

552 for P. m. mocinno and 15 individuals for P. m. costaricensis).

\begin{tabular}{ccc}
\hline & P. m. mocinno & $P$. m. costaricensis \\
\hline P. m. mocinno & 92.86 & 0.07 \\
P. m. costaricensis & 13.1 & 86.9
\end{tabular}

553

554

Table 3: RF confusion matrix used to classify the species belonging to Pharomachrus genus (total individuals is 21 for P. m. mocinno, 15 for P. m. costaricensis, 7 for $P$. antisianus, 6 for $P$. auriceps, 4 for $P$. fulgidus, 4 for $P$. pavoninus) on the basis of 22 acoustic features. Data mentioned in the text are underlined.

\begin{tabular}{cccccccc}
\hline & $P . m$. & $P . m$. & $P$. & $P$. & $P$. & $P$. & Class error \\
& mocinno & costaricensis & antisianus & auriceps & fulgidus & pavoninus & \\
\hline P. m. mocinno & $\underline{80.95}$ & 14.29 & 0.00 & 0.00 & 4.76 & 0.00 & 0.19 \\
$\begin{array}{c}\text { P. m. costaricensis } \\
\text { P. antisianus }\end{array}$ & 13.33 & $\underline{86.67}$ & 0.00 & 0.00 & 0.00 & 0.00 & 0.13 \\
$\begin{array}{c}\text { P. auriceps } \\
\text { P. fulgidus }\end{array}$ & 0.00 & 0.00 & $\underline{100.00}$ & 0.00 & 0.00 & 0.00 & 0.00 \\
P. pavoninus & 0.00 & 0.00 & 0.00 & $\underline{100.00}$ & 0.00 & 0.00 & 0.00 \\
& 25.00 & 0.00 & 0.00 & 0.00 & $\underline{75.00}$ & 0.00 & 0.25 \\
\hline
\end{tabular}

